\title{
The role of work motivation and work support and their implication towards work productivity in woman workers
}

Tentama, Fatwa $\measuredangle$

Ahmad Dahlan University Yogyakarta, Indonesia (Fatwa.tentama@psy.uad.ac.id)

Sukesi, Tri Wahyuni

Ahmad Dahlan University Yogyakarta, Indonesia (yunisukesi.fkmuad@gmail.com)

Mulasari, Surahma Asti

Ahmad Dahlan University Yogyakarta, Indonesia (surahma.mulasari@ikm.uad.ac.id)

Sulistyawati, Sulistyawati

Ahmad Dahlan University Yogyakarta, Indonesia (sulistyawatisuyanto@gmail.com)

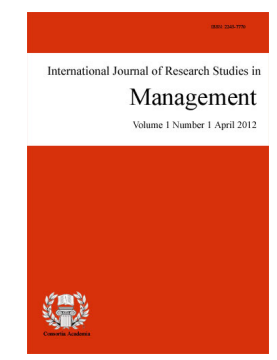

ISSN: $2243-7770$ Online ISSN: 2243-7789

OPEN ACCESS

\section{Abstract}

One of the factors related to work productivity is work motivation and work support. This study aims to examine empirically the role of work motivation and work support for work productivity in woman workers. The study population was all woman workers at the University of $X$ and a sample of 50 woman workers at University $X$. The sampling technique used purposive sampling with the characteristics of the subject, namely woman, married, having children, permanent workers and working period of more than one year. The method of data collection uses a scale of work productivity, work motivation scale, and work support scale. Data analysis with multiple linear regression. The results showed that there was a very significant contribution between work motivation and work support for work productivity. The effect of work support on work productivity is more dominant than the effect of work motivation on woman workers at University X.

Keywords: work support; work motivation; work productivity 


\section{The role of work motivation and work support and their implication towards work productivity in woman workers}

\section{Introduction}

Human Resources (HR) are a source of wealth for an organization because it functions as a driver of the organization's sustainability and determinants to achieve organizational goals (Hasibuan, 2012; Yukl, 2012). Managing and developing HR to the fullest can increase work productivity of employees to achieve organizational goals. With the achievement of the goals of the organization, the organization will be able to compete to face the challenges in the current era of globalization that is getting heavier, intense competition, rapidly developing technology, and rapid changes. Ancok (2004) emphasizes that human or employee resources are increasingly needed to develop themselves to improve employee performance to be better prepared for change. Employees must be the focus of every organization because the continuity and growth of the organization is very dependent on the productivity of its workforce, productive employees are able to improve organizational welfare (Akinyele, 2010).

According to McNeese-Smith (2001) the definition of work productivity refers to how effective and efficient an individual is in doing his work. Work productivity is defined as how efficient the work of an individual is in managing time, overcoming physical demands, relationships with coworkers and work environment and the quality and quantity of work (Lerner, Amick, Rogers, Malspeis, Bungay, \& Cynn, 2001). Boyle (2006) defines work productivity as a measure of the amount of output produced by input units. Work productivity is a measure of the level of individual functioning in work that refers to the quantity or quality of work produced (Evans, 2004).

Productivity is one of the most important and influential basic variables that regulate economic production activities (Tangen, 2005). Increasing work productivity can increase the capacity to provide the most efficient and economical products and services. Therefore organizations considering work productivity are very important given the increase in external pressures such as competition and resource costs (Deaconu, Gogu, Radu, \& Tudor, 2018). The low productivity of work results in low income and organizational poverty (Yesufu, 2001). Akinyele (2009) found that low work productivity can create a less conducive work environment.

The results of observations and interviews with several woman workers in the research locations obtained data that employees in private institutions were faced with very many jobs, both administrative and academic. Woman workers in completing varied jobs and a large number of jobs experience many problems so that their work productivity is not optimal. Woman workers can only finish work in a limited amount only, can only complete makeshift work, and often complete work beyond deadlines. This of course will have an impact on the work productivity of the organization.

Another thing that supports is the absence of electronic attendance report or manual attendance for employees so that there is no physical data / evidence regarding employee attendance every day so that employee absences cannot be quantitatively identified whether the employee comes or not and how many times the employee is present working in one week and thus make employee performance not optimal. The absence of consequences or punishments given to employees when not coming to work, not attending meetings, not being involved in the task force or committee assignments certainly makes employees work out of line with what is expected by the organization so that it will have an impact on decreasing work productivity.

\subsection{Work motivation and work productivity}

One of the predictors of low working productivity is work motivation (Banerjee, 2015; Pilourdault, 
Role of work motivation and work support and their implication towards work productivity in woman workers

Amer-Yahia, Lee, \& Roy, 2017; Rogstadius, Kostakos, Kittur, Smus, Laredo, \& Vukovic, 2011). Individuals with high work motivation tend not to feel tired easily at work, so that it will have an impact on work performance and productivity (Subandowo, 2016). According to some experts, employees with work motivation will be more productive in terms of efficiency and effectiveness, so that it will maximize the organization's income and feel more satisfied in work (Matthew, Grawhich, \& Barber, 2009). Meanwhile other experts explained that work motivation is always considered in the organization to increase work productivity (Ketkar \& Sett, 2009).

Work motivation is the drive from the individual to work caused by external factors both from the leadership and need fulfillment and satisfaction, and obligations completion (Harvey, 2006). Robbins (2006) added that work motivation is the desire to strive to achieve organizational goals. Work motivation is the psychological impulse of individuals who become determinants in behavior, level of effort, and level of persistence to deal with a problem (George \& Jones, 2005).

\subsection{Work support and work productivity}

Job support also plays a role in work productivity. Job support is a significant feature of the individual social environment and various levels of support which are expected to be available to woman workers when needed. Job support is expected to improve the performance of woman workers when faced with a stressful situation, besides that work support can also operate in the productivity process by reducing the perception or experience of work stressors and reducing the possibility of negative outcomes such as psychological symptoms that can hamper work productivity (Snow, Swan, Raghavan, Connell, \& Klein, 2003). Employment support from family and colleagues is beneficial for woman workers to integrate work, besides that individuals tend to be more responsible for their performance with the support of the work they are receiving (Voydanoff, 2005). Further, it is said that work support can reduce negative pressure and moderate psychological well-being that can improve employee performance (Brough \& Pears, 2004; Jenkins \& Elliot, 2004; Halbesleben, 2006).

Job support is an individual interaction with family members, colleagues, and peers who communicate information, appreciation, practicality, or emotional assistance (Stewart \& Lagille, 2000). In addition, work support can also be defined as work integration or work attachment that has a beneficial effect on employee welfare regardless of the condition of employees experiencing stress or not (Armstrong, Birnie-Lefcovitch, \& Ungar, 2005). Social support is psychological, material, informational, and assessment resources that are beneficial to an individual's ability to cope with stress in the face of challenges and pressures (Cohen, 2004). According to some experts work support is a resource or assistance that is exchanged between individuals through interpersonal relationships (Park, Kee, \& Valenzuela, 2009).

Based on the explanation above, the effect of work motivation and work support towards work productivity can be illustrated in the figure 1 below:

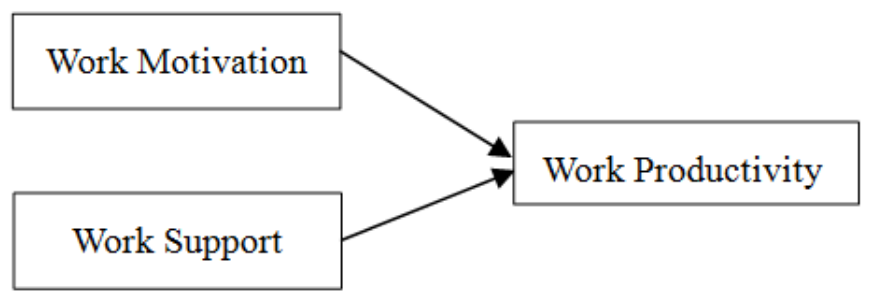

Figure 1. The effect of work motivation and work support towards work productivity

This research tries to examine empirically the role of work motivation and work support towards work productivity in woman workers. 


\section{Method}

\subsection{Population, sample and sampling technique}

The population in this study were all woman workers at the University of X. The sample of this study was 50 woman workers at the University of $\mathrm{X}$. The sampling technique used is purposive sampling with subject characteristics namely woman, married, having children, permanent employees and more than one working period year.

\subsection{Measuring instrument}

The measuring instrument consists of a scale of work productivity, work motivation, and work support. The scaling model used is the Likert scaling model. Work productivity is revealed by the scale of work productivity by referring to the factors used in measuring work productivity according to Simamora (2004) including quantity of work, quality of work and timeliness. Work motivation is revealed by the work motivation scale with reference to aspects of work motivation according to Herzberg (Robbin, 2003), namely security, opportunity, type of work, work colleagues, company, salary, supervision, and working hours. Job support is revealed by the scale of work support based on aspects of social support according to House and Khan (Smet, 1994), namely aspects of emotional attention, information, instrument and positive judgment.

\subsection{Validity and reliability of measuring instrument}

The validity in this study uses content validity, which is the estimated validity through testing the contents of the test through professional judgment or through rational analysis. Content validity with professional judgment is carried out with item examination by requesting consideration from competent/expert parties. Reliability is based on the consistency of the measurement results that contain the meaning of accuracy in measurement. Reliability testing uses an internal consistency approach where in the procedure only require a single trial admission to a group of individuals as a sample. Reliability estimation technique used is alpha coefficient technique from Cronbach.

On the scale of work productivity with the test subjects 30 woman workers obtained the reliability coefficient of .909. The index of the different power item (corrected item-total correlation) moves from .270 to .793 . Valid and reliable items that are used for research are 18 items. While, on the work motivation scale with the test subjects 30 woman workers obtained the reliability coefficient of .939. The corrected item-total correlation index moves from .410 to .780 . Valid and reliable items that are used for research are 30 items. Lastly, for the scale of work support with the trial subjects 30 woman workers obtained the reliability coefficient of 0.934. The power difference index (corrected item-total correlation) index moves from .487 to .801 . Valid and reliable items that are used for research are 20 items.

\subsection{Data analysis}

Data analysis used is multiple linear regression to examine the effect of work motivation and work support on work productivity. Before hypothesis testing, assumption tests were carried out, namely normality test, linearity test and multicollinearity test. Data analysis is done with SPSS 19.0 program.

\section{Results}

\subsection{Prerequisite Test}

Normality test - Table 1 shows the significance value $(p)$ of work productivity, work motivation, and work support of $.065, .213$, and .119 which has $p>.05$ so that each data is normally distributed, meaning the sample 

used can represent the population.

\section{Table 1}

Normality test

\begin{tabular}{lccc}
\hline \multicolumn{1}{c}{ Variable } & Score K-SZ & Sig. & Explanation \\
\hline Work productivity & 1.309 & .065 & Normal \\
Work motivation & 1.058 & .213 & Normal \\
Work support & 1.188 & .119 & Normal \\
\hline
\end{tabular}

Linearity test - The results of linearity test obtained F linearity on work motivation on work productivity of 27.330, a significance value $(p)$ of .000 which means linear or there is a line that connects between work motivation variables and work productivity. The work support linearity test results on work productivity obtained F linearity of 41,707 with a significance value $(p)$ of .000 which means linear or there is a straight line that connects between work support and work productivity.

Table 2

Linearity test

\begin{tabular}{lcccc}
\hline \multicolumn{1}{c}{ Variable } & F Linearity & Sig & Rule & Explanation \\
\hline Work motivation & 27.330 & .000 & $p<.01$ & Linear \\
Work support & 41.707 & .000 & $p<.01$ & Linear \\
\hline
\end{tabular}

Multicollinearity test - The table below shows that work motivation and work support have VIF values = 1.297 (VIF < 10) and tolerance $=.771$ (tolerance $>.1$ ) so that there is no multicollinearity between work motivation and work support.

\section{Table 3}

Multicollinearity test

\begin{tabular}{lccc}
\hline \multicolumn{1}{c}{ Variable } & Tolerance & VIF & Explanation \\
\hline Work motivation & .771 & 1.297 & No multicollinearity \\
Work support & .771 & 1.297 & No multicollinearity \\
\hline
\end{tabular}

\subsection{Multiple regression test}

The results of the t-test analysis showed that the effect of work motivation on work productivity was $(\mathrm{t})=$ 3.885 with $\mathrm{p}=.000(p<.01)$, meaning that there was a very significant effect between work motivation on work productivity on woman workers at University $X$. The results of the $t$ test of work support for work productivity obtained a value $(\mathrm{t})$ of $=4.043$ with $\mathrm{p}=.000(p<.01)$, meaning that there is a very significant effect of work support on work productivity on woman workers at University X.

\section{Table 4}

T-test

\begin{tabular}{lcccc}
\hline \multicolumn{1}{c}{ Variable } & $t$ & Sig & Rule & Explanation \\
\hline Work motivation towards work productivity & 3.885 & .000 & $p<.01$ & There is a very significant influence \\
Work support towards work productivity & 4.043 & .000 & $p<.01$ & There is a significant influence \\
\hline
\end{tabular}

The results of regression $\mathrm{F}$ test analysis simultaneously show the value of $\mathrm{F}=30.157$ with $p=.000, p<.01$, which means that work motivation and work support simultaneously influence work productivity on woman workers at University X. The amount of contribution to work motivation and work support influences the work productivity is indicated by the Adjusted $\mathrm{R}$ Square value $=.543$ which means that the contribution of work motivation and work support variables is $54.3 \%$ and the remaining $45.7 \%$ comes from other factors. 
Table 5

F test

\begin{tabular}{lcccc}
\hline \multicolumn{1}{c}{ Variable } & $\begin{array}{c}\text { Adjusted R } \\
\text { Square }\end{array}$ & Sig & Rule & Explanation \\
\hline $\begin{array}{l}\text { Work motivation and work support } \\
\text { towards work productivity }\end{array}$ & 41.707 & .000 & $p<.01$ & $\begin{array}{c}\text { There is a very } \\
\text { significant influence }\end{array}$ \\
\hline
\end{tabular}

\section{Discussion}

The results of the regression analysis found that work motivation and work support simultaneously affect the work productivity of woman workers so that work productivity can be predicted based on work motivation and work support. Thus woman workers need internal factors from themselves and external factors from the surrounding environment to achieve work productivity. Woman workers who are married and have children are certainly different from male workers who want to fulfill the obligation to take care of their families, both their children and their husbands, which is carried out together with their responsibilities to complete the maximum work. Woman workers who have high work motivation and receive social support from various parties, both coworkers and superiors, will be able to achieve the quantity of work that is targeted, achieve maximum work quality and be on time in completing tasks.

The results obtained are relevant to the findings of previous studies and broaden the understanding of the mechanism by which work motivation contributes to increased work productivity (Pilourdault, Amer-Yahia, Lee, \& Roy, 2017; Rogstadius, Kostakos, Kittur, Smus, Laredo, \& Vukovic, 2011). Work motivation affects the percentage of work time spent productively, which means work motivation is related to work productivity (Olomolaiye, 2013). Motivated employee can improve work productivity efficiency higher (Luintel, Selim, \& Bajracharya, 2017). Psychological conditions in the form of motivation greatly affect individual performance to remain competitive and networked (Doloi, 2007).

Woman workers who get work motivation both internally and externally will increase their productivity at work. Internal motivation includes woman workers feeling a sense of security and comfort while working so that they do not feel stressed and threatened in their working lives, woman workers will also be eager to work if given the opportunity to complete their work, be given the opportunity to complete the appropriate work and be given the opportunity in promotion. In addition, the work motivation of woman workers will also increase if supported by an appropriate salary, good supervision from employers and working hours that support their status as woman workers who have family and children. Thus the perceived work motivation will be able to influence the achievement of work productivity produced by woman workers for their organization, namely achieving the expected quantity of work, achieving maximum quality of work and timely completion of tasks.

Another factor that affects the work productivity of woman workers is the work support that workers get. The results obtained are supported by the assumed theory and also some other results of research that found that work support can protect individuals from potentially dangerous effects of stressful events and have the effect of supporting stressors, stresses, and physical and mental health which can inhibit employee work productivity (Armstrong, Birnie-Lefcovitch, \& Ungar, 2005). Job support from colleagues plays an important role in moderating the effects of the level of work fatigue (Zapf, Seifert, Schmutte, Mertini, \& Holz, 2001). A cross-sectional study found that a low or inadequate level of work support can cause a decrease in the productivity of woman employees (Kulhara Basu, Mattoo, Sharan, \& Chopra, 1999). Employees with limited work support lack the opportunity to discuss how problems are actually being faced in relation to work productivity (Mann, 2002; Ersoy-Kart, 2009).

Woman workers who get work support both from their families, especially their husbands, co-workers, or superiors will have a positive impact on their work behavior, the moral burden at work will be lighter and will focus more on work which will ultimately have an impact on their work productivity. The feeling of empathy, 
Role of work motivation and work support and their implication towards work productivity in woman workers

attention and care that is given by the family (husband), coworkers or superiors accompanied by giving advice, direction, suggestions or positive criticism in the face of work problems faced will make all work problems can be resolved and easily resolved so that the quantity of work expected can be achieved to reach work quality and timeliness in completing tasks. Thus both work motivation and work support contribute significantly to the productivity of woman workers.

Work motivation and work support contribute $54.3 \%$ to work productivity so the remaining $45.7 \%$ can be influenced by other factors outside of work motivation and work support variables. Other factors that influence work productivity include personality, work ethic, perception of the role of work, environment, labor market, the influence of regulations, and workplace conditions (Sandqvist \& Henriksson, 2004). Partially the results of this study indicate that work motivation contributes to work productivity of $27.3 \%$ and contribution of work support to work productivity is $28.9 \%$. The influence of work support is more dominant in contributing to the productivity of woman workers at University X.

\section{Conclusion and implications}

The conclusion in this study is that work motivation and work support have a role in increasing work productivity both simultaneously and partially. The role of work support on work productivity is more dominant than the role of work motivation in woman workers at University X. Thus in addition to internal factors, external factors apparently also need to be considered by the organization as an effort to increase employee work productivity.

The implications of this study are expected to be a consideration for University $\mathrm{X}$ to pay more attention to work motivation and work support as factors that support work productivity by creating a positive work environment such as a safe and comfortable working atmosphere, good supervision of the leadership, working hours that support woman workers, creating cohesiveness among colleagues and even paying attention to the salaries received by woman workers in particular. In addition, it is also a consideration of the importance of conducting work motivation training as an effort to foster a spirit of work and a strong desire to work to achieve organizational goals. Thus the higher the level of work motivation and the higher the work support for the work productivity will be. For female workers, provide understanding and awareness that external factors are very important in supporting work, namely family support (husband), coworkers, and superiors who will have a positive impact on work behavior.

Acknowledgements: The researcher extends the deepest gratitude to the Women's Study Center and the Institute for Research and Community Service of Ahmad Dahlan University in Yogyakarta that has funded this research and assisted in the licensing process and research.

\section{References}

Akinyele, S. T. (2009). The influence of work environment on workers productivity: A case of selected oil and gas industry in Lagos, Nigeria. African Journal of Business Management, 4(3), 299-307.

Akinyele, S. T. (2010). A critical assessment of environmental impact on workers productivity in Nigeria. Research Journal on Business Management, 4(1), 61-72.

Ancok, D. (2004). Applied psychology (Psikologi terapan). Yogyakarta: Darussalam.

Armstrong, M. I., Birnie-Lefcovitch, S., \& Ungar, M. T. (2005). Pathways between social support, family well-being, quality of parenting, and child resilience: What we know. Journal of Child and Family Studies, 14(2), 269-281. https://doi.org/10.1007/s10826-005-5054-4

Banerjee, A. (2015). Integrating human motivation in service productivity. Procedia Manufacturing, 3, 3591-3598. https://doi.org/10.1016/j.promfg.2015.07.726

Boyle, R. (2006). Measuring public sector productivity: Lessons from international experience. Dublin: Institute 
of Public Administration.

Brough, P., \& Pears, J. (2004). Evaluating the influence of the type of social support on job satisfaction and work related psychological well-being. International Journal of Organisational Behaviour, 8(2), 472-485.

Cohen, S. (2004). Social relationships and health. American Psychologist, 59(8), 676-684. https://doi.org/10.1177/0022146510383501

Doloi, H. (2007). Twinning motivation, productivity and management strategy in construction projects. Engineering Management Journal, 19(3), 30-40. https://doi.org/10.1080/10429247.2007.11431738

Ersoy-Kart, M. (2009). Relations among social support, burnout and experiences of anger: An investigation among emergency nurses. Nursing Forum, 44(3), 165-174. https://doi.org/10.1111/j.1744-6198.2009.00139.x

Evans, C. J. (2004). Health and work productivity assessment: State of the art or state of flux?. Journal of Occupational and Environmental Medicine, 46(6), 3-11. http://dx.doi.org/10.1097/01.jom.0000126682.37083.fa

George, J. M., \& Jones, G. R. (2005). Essentials of managing organizational behavior. New Jersey: Upper Saddle River.

Grawhich, M. J., \& Barber, L. K., (2009). Are you focusing both employees and organizational out comes. Organizational Health Initiative at Saint Louis University, 1-5. https://doi.org/10.1037/e513342011-002

Halbesleben, J. R. (2006). Sources of social support and burnout: A meta-analytic test of the conservation of resources model. Journal of Applied Psychology, 91(5), 1134-1145. http://dx.doi.org/10.1037/0021-9010.91.5.1134

Harvey. (2006). Motivation and work behavior. New York: Accademic Press.

Hasibuan, M. S. P. (2012). Human resource management (Manajemen sumber daya manusia). Jakarta: Bumi Aksara.

Jenkins, R., \& Elliot, P. (2004). Stressors, burnout and social support: Nurses in acute mental health settings. Journal of Advanced Nursing, 48(6), 622-631. https://doi.org/10.1111/j.1365-2648.2004.03240.x

Ketkar, S., \& Sett, P. K. (2009). HR flexibility and firm performance: Analysis of a multi-level causal model. The International Journal of Human Resource Management, 20(5), 1009-1038. https://doi.org/10.1080/09585190902850240

Kulhara, P., Basu, D., Mattoo, S. K., Sharan, P., \& Chopra, R. (1999). Lithium prophylaxis of recurrent bipolar affective disorder: Long-term outcome and its psychosocial correlates. Journal of Affective Disorders, 54(1-2), 87-96. https://doi.org/10.1016/S0165-0327(98)00145-1

Lerner, D., Amick, B. C., Rogers, W. H., Malspeis, S., Bungay, K., \& Cynn, D. (2001). The work limitations questionnaire. Medical Care, 39(1), 72-85. https://doi.org/10.1097/00005650-200101000-00009

Luintel, K. B., Selim, S., \& Bajracharya, P. (2017). Liberalization, bankers' motivation and productivity: A simple model with an application. Economic Modelling, 61, 102-112. https://doi.org/10.1016/j.econmod.2016.11.017

Mann, S. (2003). Hiding what we feel, faking what we don't: Understanding the role of your emotions at work. London: Vega.

McNeese-Smith, D. K. (2001). Staff nurse views of their productivity and nonproductivity. Health Care Management Review, 26(2), 7-19. https://doi.org/10.1097/00004010-200104000-00002

Olomolaiye, P. O. (2013). An evaluation of the relationships between bricklayers' motivation and productivity. Construction Management and Economics, 8(3), 37-41. https://doi.org/10.1080/01446199000000025

Park, N., Kee, K. F., \& Valenzuela, S. (2009). Being immersed in social networking environment: Facebook groups, uses and gratifications, and social outcomes. CyberPsychology \& Behavior, 12(6), 729-733. https://doi.org/10.1089/cpb.2009.0003

Pilourdault, J., Amer-Yahia, S., Lee, D., \& Roy, S. B. (2017). Motivation-aware task assignment in crowdsourcing. In the Proceedings of the 20th international conference on extending database technology (pp. 246-257). https://doi.org/10.5441/002/edbt.2017.23

Robbins, S. P. (2003). Organizational behaviour concept, contoversiest, applications. New Jersey: Prentice Hall. Robbins, S. P. (2006). Organisational behaviour. San Diego: Prentice Hall. 
Role of work motivation and work support and their implication towards work productivity in woman workers

Rogstadius, J., Kostakos, V., Kittur, A., Smus, B., Laredo, J., \& Vukovic, M. (2011). An assessment of intrinsic and extrinsic motivation on task performance in crowdsourcing markets. In the Proceedings of the Fifth International AAAI conference on weblogs and social media (pp. 321-328). Menlo Park, CA: AAAI Press.

Sandqvist, J. L., \& Henriksson, C. M. (2004). Work functioning: A conceptual framework. Work, 23(2), 147-157.

Smet, B. (1994). Health psychology (Psikologi kesehatan). Jakarta: Grasindo.

Snow, D. L., Swan, S. C., Raghavan, C., Connell, C. M., \& Klein, I. (2003). The relationship of work stressors, coping and social support to psychological symptoms among woman secretarial employees. Work \& Stress, 17(3), 241-263. https://doi.org/10.1080/02678370310001625630

Stewart, M. J., \& Lagille, L. (2000). A framework for social support assessment and intervention in the context of chronic conditions and caregiving. Toronto: University of Toronto Press.

Subandowo, M. (2016). The effect of training on work motivation, attitude, fatigue, and productivity. International Journal of Management and Administrative Sciences, 3(7), 41-52.

Tangen, S. (2005). Demystifying productivity and performance. International Journal of Productivity and Performance Management, 54(1), 34-46. https://doi.org/10.1108/17410400510571437

Voydanoff, P. (2005). Toward a conceptualization of perceived work-family fit and balance: A demands and resources approach. Journal of Marriage and Family, 67(4), 822-836. https://doi.org/10.1111/j.1741-3737.2005.00178.x

Yesufu, T. M. (2001). The human factor in national development: Nigeria. Ibadan: Spectrum Books Limited. Yukl, G. A. (2012). Leadership in organizations. London: Pearson.

Zapf, D., Seifert, C., Schmutte, B., Mertini, H., \& Holz, M. (2001). Emotion work and job stressors and their effects on burnout. Psychology and Health, 16(5), 527-545. https://doi.org/10.1080/08870440108405525 
Tentama, F., Sukesi, T. W., Mulasari, S. A., \& Sulistyawati, S. 